\title{
KOPERASI SEKOLAH SEBAGAI WADAH PENGEMBANGAN KARAKTER SISWA
}

\author{
Sukidjo, Ali Muhson, \& Mustofa \\ Universitas Negeri Yogyakarta, Indonesia \\ Email: sukidjo_uny@yahoo.com
}

\begin{abstract}
Abstrak: Koperasi Sekolah Sebagai Wadah Pengembangan Karakter Siswa. Tujuan penelitian ini adalah menganalisis implementasi model pengembangan koperasi siswa (kopsis) sebagai model pendidikan karakter di SMK. Penelitian ini mengambil sampel sekolah sebanyak 20 SMK di Provinsi DIY. Pengembangan kopsis sebagai model pendidikan karakter menggunakan Research and Development. Penelitian ini berhasil menyusun buku panduan penerapan model pengembangan kopsis. Penelitian ini juga berhasil membuktikan bahwa kegiatan berkoperasi mampu menumbuhkan nilai karakter seperti kekeluargaan, kemandirian, tanggung jawab, dan demokrasi.
\end{abstract}

Kata Kunci: Pengembangan Koperasi, pendidikan karakter

\begin{abstract}
Cooperative Student for Developing Students Character. The purpose of this study was to analyze the implementation of cooperative student development model as a model as character education in Vocational High School (SMK). The samples of this study are 20 SMK in DIY. Cooperative Student development, as a model of character education, uses the Research and Development. This study managed to compile a guidebook of Cooperative Student development. The study also proved that the activities in student cooperative were able to develop the character values such as kinship, independence, responsibility, and democracy.
\end{abstract}

Keywords: Cooperative development, character education.

\section{PENDAHULUAN}

Koperasi merupakan salah satu organisasi ekonomi yang melandaskan kegiatannya berdasarkan prinsip gerakan ekonomi rakyat yang berdasarkan asas kekeluargaan. Koperasi Indonesia memiliki dasar konstitusional yang kuat, sebagaimana yang tercantum dalam UUD 1945 pasal 33 ayat 1 yang berbunyi, "Perekonomian disusun sebagai usaha bersama berdasarkan atas asas kekeluargaan". Dasar konstitusional tersebut juga diperkuat dengan UndangUndang Nomor 25 Tahun 1992 tentang perkoperasian. "Koperasi adalah badan usaha yang beranggotakan orang-orang atau badan hukum koperasi dengan melandaskan kegiatannya berdasarkan prinsip koperasi sekaligus sebagai gerakan ekonomi rakyat yang berdasarkan atas asas kekeluargaan".

Adapun tujuan koperasi di Indonesia sesuai pasal 3 UU Nomor 25 Tahun 1992 adalah untuk meningkatkan kesejahteraan anggotanya, meningkatkan kesejahteraan masyarakat, dan turut serta dalam membangun tatanan perekonomian Indonesia. Sejahtera dapat diartikan sebagai kondisi sudah mampu memenuhi kebutuhan hidupnya atau sudah mandiri dalam memenuhi kebutuhan hidupnya.

Kemandirian warga negara, hendaknya mulai dipupuk sejak usia dini melalui lembaga pendidikan sekolah. Dengan ditanamkannya karakter kemandirian sejak usia dini maka ketika menginjak usia dewasa 
di dalam diri seorang warga negara tersebut akan tertanam jiwa kreativitas dan memiliki kemampuan untuk menemukan inovasiinovasi baru yang diharapkan dapat menyelesaikan masalah yang ada dalam kehidupan sehari-hari.

Perilaku kemandirian di sekolah diperlukan agar seorang siswa mengetahui bagaimana mahasiswa dapat bertanggung jawab serta percaya diri dan mampu memecahkan permasalahan yang ada baik pribadi ataupun orang lain. Sekolah merupakan salah satu lembaga yang bertanggungjawab untuk mengembangkan perilaku kemandirian yang akan diwujudkan terhadap siswa melalui Koperasi Sekolah atau Koperasi Siswa (Kopsis).

Sekolah Menengah Kejuruan (SMK) sebagai salah satu lembaga pendidikan mempunyai tujuan menyiapkan lulusan agar dapat bekerja secara mandiri sesuai dengan bidang dan program keahlian yang dimiliki. SMK harus mampu melahirkan lulusan yang bermutu, memiliki pengetahuan, menguasai teknologi, terampil, dan memiliki kecakapan hidup yang memadai. SMK sebagai pendidikan vokasional dituntut untuk menghasilkan tenaga-tenaga profesional yang memiliki kemampuan kewirausahaan (Renstra Depdiknas, 2010-2014: 60).

Suatu bangsa atau negara akan mampu membangun ekonomi apabila memiliki wirausahawan sebanyak $2 \%$ dari jumlah penduduk (Buchori, 2005: 4-5). Di Indonesia jumlah wirausahawan sangat sedikit, bahkan dibandingkan dengan negara tetangga seperti Malaysia dan Singapura. Menurut survey Bank Dunia tahun 2008, wirausahawan Malaysia mencapai 4\%, Thailand 4,1\%, dan Singapura 7,2\%, di
Indonesia hanya berjumlah 1,56\% (Boediono, 2012).

Entrepreneurial is not magic, it's not mysterious, and it has nothing to do with the genes. It's a discipline. And, like any discipline, it can be learned (Drucker, 1985). An "entrepreneurial perspective" can be developed in individuals (Kuratko, 2005) and entrepreneurship is a discipline that can be taught (Tonelli \& Dalglish, 2012; Henry, Hill, \& Leitch, 2005), bahkan kewirausahaan dapat diajarkan tidak hanya untuk pengusaha tetapi untuk semua orang (Sarasvathy \& Venkataraman, 2011). Oleh karena itu SMK memiliki peran yang sangat strategis dalam meningkatkan jumlah wirausahawan di Indonesia.

The benefits of entrepreneurship education are not limited to start-ups, innovative ventures and new jobs. Entrepreneurship refers to an individual's ability to turn ideas into action and is therefore a key competence for all, helping young people to be more creative and selfconfident in whatever they undertake (European Commission, 2008: 7). Hal ini berarti pendidikan kewirausahaan tidak hanya sekedar memberikan bekal kepada siswa tentang bagaimana memulai usaha melainkan juga bagaimana menuangkan idenya dalam bentuk tindakan yang nyata sehingga dapat menjadikan siswa lebih kreatif dan percaya diri.

Pengembangan kewirausahaan sekolah berbasis kreativitas dan inovasi dapat memberikan pengalaman belajar yang berharga bagi siswa. Pemanfaatan koperasi sekolah dapat dijadikan sebagai tempat praktik langsung siswa dalam mengasah keterampilan dan keahliannya. Pengelolaan 
koperasi sekolah selain sebagai media pembelajaran, juga dapat memberikan sumbangsih dalam menambah penghasilan sekolah dan membantu membangun perekonomian masyarakat.

Salah satu peran koperasi siswa ini adalah agar para siswa tumbuh jiwa setia kawan, saling menghargai, kesamaan derajat dan gotong royong antar sesamanya dan menumbuhkan serta mengasah demokrasi, kreativitas, kemampuan, pengetahuan dan lain sebagainya. Di samping itu, koperasi sekolah dapat memiliki peran dalam memasyarakatkan koperasi melalui pendidikan ekonomi dan koperasi di sekolah. Salah satu tujuan yang diharapkan adalah para siswa yang telah lulus nanti dapat mendirikan koperasi ataupun mewarisi nilainilai karakter dalam kegiatan berkoperasi.

Menurut Priambodo (2006 : 87) koperasi sekolah memiliki nilai dan potensi yang strategis dan menjadi aktor utama untuk mengatasi permasalahan perluasan kesempataan kerja dan pertumbuhan wirausaha baru. Melalui kegiatan koperasi sekolah, para lulusan SD, SMP dan SMTA yang tidak melanjutkan sekolah, dipersiapkan untuk memiliki alternatif menjadi pencari kerja atau menjadi wirausaha. Letak strategis koperasi sekolah diwujudkan dalam bentuk menyiapkan secara dini mental dan jiwa kewirausahaan anak sejak di bangku sekolah dasar, memberikan alternatif untuk menjadi pencari kerja atau orang yang menciptakan kerja sebagai wirausaha. Keberadaan koperasi sekolah dapat digunakan sebagai wahana pembelajaran berkoperasi dan berusaha untuk mengasah dan mengembangkan potensi kewirausahaan sehingga nantinya mereka memiliki alternatif menjadi wirausaha mandiri atau sebagai pencari kerja. Alternatif tersebut dimungkinkan sebab koperasi sekolah sebagai badan usaha memberikan manfaat ganda terhadap para siswa sebagai anggota koperasi sekolah. Pertama, siswa dapat secara langsung mengenal, melihat, dan mempraktekkan teori dalam kehidupan nyata di koperasi sekolah. Kedua, koperasi sekolah digunakan sebagai wahana pembelajaran berusaha, sehingga siswa memperoleh pengetahuan dan keterampilan berusaha yang bermanfaat untuk menumbuhkaan jiwa kewirausahaan yang berakibat tumbuhnya keberanian untuk berusaha secara mandiri sehingga mampu meciptakan lapangan kerja dan mengurangi pengangguran dan kemiskinan. Di sinilah perlunya upaya penanaman pendidikan karakter dalam diri setiap siswa.

Character education is briefly defined as knowing the good, loving the good, and doing the good (Jones et al., 1999). Pengertian lebih luas disampaikan oleh Wiliams (2000) yang menyatakan bahwa character education is more holistic and comprehensive, incorporating more aspects of child development that include the cognitive, affective, and behavioral domains. Hal ini menunjukkan bahwa pendidikan karakter tidak hanya sebatas pengetahuan saja melainkan harus masuk pada ranah sikap dan perilaku.

Pendidikan karakter bukan sekedar mengajarkan mana yang salah, lebih dari itu pendidikan karakter menanamkan kebiasaan (habituation) tentang hal yang baik sehingga peserta didik menjadi faham (domain kognitif) tentang mana yang baik dan salah, 
mampu merasakan (domain afektif) nilai baik dan biasa melakukannya (domain perilaku) (Zuchdi, 2009:10). Lebih jauh lagi Lickona (1996) menyatakan bahwa "as people grow in their character they will develop an increasingly refined understanding of the core values, a deeper commitment to living according to those values and a stronger tendency to behave in accordance with those values". Oleh karena itu pendidikan karakter yang baik, harus melibatkan bukan saja aspek pengetahuan yang baik (moral knowing), tetapi juga merasakan dengan baik atau (moral feeling) dan perilaku yang baik (moral action) (Kemdiknas, 2010). Dengan demikian pendidikan karakter lebih menekankan pada penanaman kebiasaan yang baik untuk terusmenerus dipraktikkan dalam kehidupan sehari-hari.

Pada saat ini seorang siswa dituntut menjadi seorang yang berkarakter mandiri, sehingga memiliki jiwa entrepreneur agar mereka siap dalam menghadapi persaingan global. Karakter menunjukkan bagaimana siswa bertingkah laku. Apabila siswa berperilaku tidak peduli atau egois, tidak jujur, dan tidak tanggung jawab maka dapat dikatakan siswa tersebut memanisfestasikan perilaku buruk. Sebaliknya, apabila siswa berperilaku jujur, bertanggung jawab, suka menolong, tentulah orang tersebut memanifestasikan karakter mulia. Schools must help children understand core values, adopt or commit to them, and then act upon them in their own lives (Lickona, 1993). Oleh karena itu integrasi pendidikan karakter dalam pembelajaran di sekolah mutlak diperlukan.

Integrasi nilai-nilai karakter bangsa dapat dilakukan pada kegiatan pembelajaran semua mata pelajaran di sekolah untuk menyiapkan lulusan menguasai kompetensi dan sekaligus mengaplikasikan nilai-nilai karakter bangsa pada kehidupan sehari-hari (Ghufron, 2010). Pelaksanaan pendidikan karakter didukung penuh oleh semua komponen sekolah, baik kepala sekolah dan wakilnya, semua guru, orang tua, pengawas sekolah, maupun siswa (Buchory \& Swadayani, 2014). Dengan cara tersebut diharapkan hasilnya menjadi lebih optimal.

Beberapa penelitian membuktikan bahwa melalui integrasi pendidikan karakter dalam pembelajaran mampu meningkatkan pemahaman terhadap nilai-nilai karakter (Suranto 2014; Tanjung \& Ramadhani, 2013). Oleh karena itu pengembangan karakter dilakukan secara terintegrasi ke dalam mata pelajaran, pengembangan diri dan budaya satuan pendidikan.

Nilai-nilai karakter yang dapat ditanamkan dapat didasarkan pada nilai-nilai kebajikan yang terkandung dalam kehidupan keagamaan, budaya dan kebangsaan. Banyak sekali nilai-nilai karakter yang dapat ditanamkan dalam pendidikan karakter. Misalnya kindness, honesty, loyalty, and compassion (Ryan, 1993); wisdom, honesty, kindness, and self-discipline (Lickona, 1999). Nilai-nilai tersebut juga dirangkum oleh Pearson \& Nicholson (2000) yang meliputi responsibility honesty, respect, fairness, trustworthiness, caring, justice, civic virtue, kindness, empathy, self-respect, selfdiscipline, and courage.

Pendidik dan satuan pendidikan perlu mengintegrasikan pendidikan karakter ke dalam pembelajaran. Siswa belajar melalui proses berpikir, bersikap, dan berbuat. Ketiga proses ini dimaksudkan untuk 
mengembangkan kemampuan siswa dalam sikap spiritual, sikap sosial, dimensi pengetahuan dan dimensi keterampilan (Kemdiknas, 2004). Direct character education is most effective when combined with opportunities for acting upon the character lessons (Lickona, 2000). Hal ini menunjukkan bahwa pendidikan karakter akan lebih bermakna jika tidak hanya diberikan dalam bentuk wawasan melainkan lebih banyak dalam bentuk praktik secara langsung. Di sinilah peran kopsis menjadi penting dalam penanaman karakter pada siswa.

Koperasi siswa (Kopsis) di SMK dapat diposisikan sebagai kegiatan intrakurikuler maupun ekstrakurikuler. Kopsis sebagai kegiatan intrakurikuler dimaksudkan sebagai wahana praktik dari mata pelajaran ekonomi pada topik badan usaha atau sebagai tempat praktik mata pelajaran kewirausahaan. Kopsis sebagai kegiatan ekstrakurikuler dimaksudkan sebagai sarana untuk mengembangkan semangat kebersamaan, kejujuran, kemandirian, kepedulian, dan tanggung jawab melalui kegiatan mengelola usaha toko koperasi sekolah.

Kegiatan usaha yang dapat dilakukan kopsis, antara lain menyelenggarakan usaha pertokoan, usaha kafetaria, pengadaan alatalat sekolah, pengadaan seragam, pengadaan alat-alat laboratorium serta kegiatan simpan pinjam. Melalui usaha pertokoan kopsis, para siswa dibimbing guru untuk mengembangkan sifat kebersamaan dalam mengelola kopsis, melakukan pembukuan atau pencatatan transaksi secara jujur, memupuk rasa tanggung jawab melalui penyelenggaraan laporan pertanggungjawaban pengelolaan kopsis pada setiap akhir tahun yang disampaikan dalam forum Rapat Anggota Tahunan (RAT).

Pengembangan sifat kemandirian dan sifat kewirausahaan dilakukan melalui pemberian tugas untuk pengelolaan usaha kopsis. Penanaman nilai-nilai kerjasama, kejujuran, kemandirian, kepedulian, tanggung jawab dapat juga dilakukan pada bidang usaha kafetaria (kantin), simpan pinjam, pengadaan alat tulis, pengadaan alat-alat laboratorium maupun usaha di bidang pengadaan bahan-bahan seragam siswa. Demikian juga pada kegiatan ekstrakurikuler yang lain misalnya kegiatan yang dilakukan dalam kegiatan kepramukaan. Model penanaman nilai-nilai luhur yang dilakukan melalui kopsis dipandang lebih strategis, karena siswa secara langsung melihat, memahami dan menghayati dan menerapkan nilai-nilai yang terkandung dalam pendidikan karakter melalui praktik berkoperasi di kopsis sekaligus mengembangkan jiwa kewirausahaan. Dalam mengembangkan kopsis, secara langsung siswa dilatih, diberdayakan melalui kegiatan usaha yang dilandasi sifat kebersamaan, kejujuran, kedisiplinan, demokrasi, kemandirian dan tanggung jawab sehingga secara tidak langsung membantu mempercepat pencapaian tujuan pendidikan karakter. Oleh sebab itu, jika keberadaan koperasi dikembangkan maka secara tidak langsung membantu mengembangkan pendidikan karakter dan kewirausahaan.

Dalam menjalankan kegiatannya, koperasi mendasarkan diri dua kelompok nilai, yaitu (1) nilai yang mendasari kegiatan dan (2) nilai yang diyakini oleh anggota. Nilai yang mendasari kegiatan ada tujuh nilai, 
yaitu (1) kekeluargaan, (2) menolong diri sendiri, (3) bertanggung jawab, (4) demokrasi, (5) persamaan, (6) berkeadilan dan (7) kemandirian. Sedangkan nilai yang diyakini anggota ada 4 nilai, yaitu (1) kejujuran, (2) keterbukaan, (3) tanggung jawab dan (4) kepedulian terhadap orang lain.

Berbagai nilai yang ada pada koperasi ternyata sangat mendukung dalam pendidikan karakter. Oleh sebab itu, dengan dikembangkannya koperasi diharapkan akan mempercepat pemahaman dan penguasaan nilai-nilai yang dikembangkan dalam pendidikan karakter, sehingga para warga masyarakat nantinya akan memiliki sifat dan perilaku yang dilandasi oleh nilai-nilai luhur, seperti kebersamaan, kepedulian, kejujuran, berkeadilan dan bertanggungjawab. Di lain pihak, keberadaan koperasi akan eksis apabila didukung oleh pemahaman dari seluruh pemangku kepentingan terhadap nilai-nilai yang berupa keterbukaan demokrasi, partisipasi, kemandirian, kerjasama, pendidikan dan kepedulian kepada masyarakat (Sukidjo, 2008: 199). Hal ini sesuai dengan pendapat J. Handoyo Mulyo (2007) yang menyatakan bahwa faktor kunci sukses pemberdayaan koperasi meliputi: pemahaman mengenai jati diri koperasi, kebutuhan kolektif anggota, sinergisme usaha koperasi dengan anggota serta kesungguhan dalam pengelolaan.

Penelitian ini bermaksud untuk menganalisis implementasi model pengembangan koperasi siswa (kopsis) sebagai model pendidikan karakter di SMK dan dampaknya terhadap nilai-nilai kejujuran, kedisiplinan, kerjasama, kekeluargaan, kemandirian, tanggung jawab, dan demokrasi. Hasil yang diharapkan adalah tersusunnya buku panduan pengembangan koperasi sekolah.

\section{METODE}

Jenis penelitian adalah penelitian deskriptif. Deskriptif karena mendeskripsikan secara mendalam tentang kesiapan sekolah dalam mengimplementasikan kurikulum dan berusaha menggali faktor-faktor yang

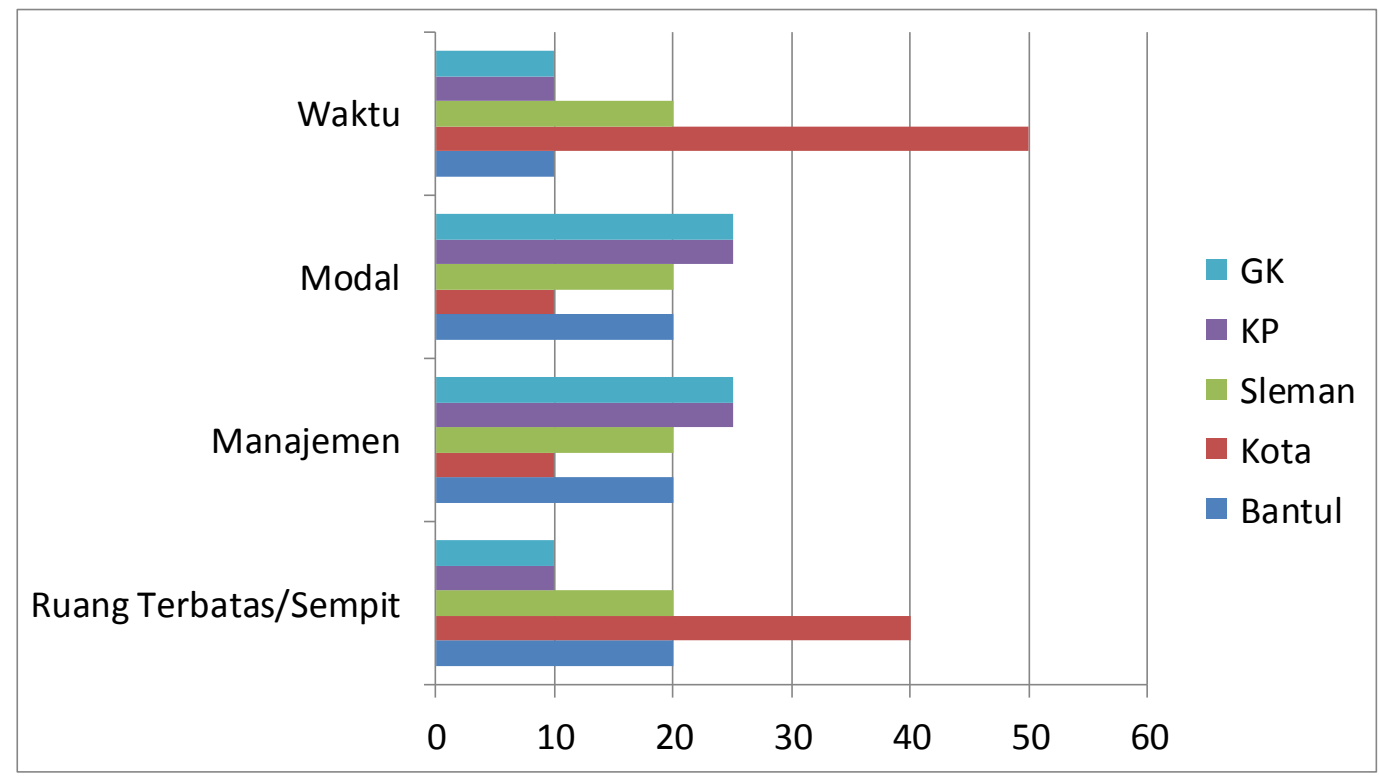

Gambar 1. Faktor penghambat 
mempengaruhinya (baik mendukung maupun menghambat). Subjek penelitian ini adalah kepala sekolah, pengurus koperasi dan siswa. Objek penelitian ini adalah profil atau kondisi koperasi siswa serta factor pendukung dan penghambat perkembangan koperasi siswa di SMK.

Teknik sampling yang digunakan adalah purposive sampling. Penetapan sampel didasarkan pada jenis sekolah, yaitu sekolah kejuruan teknik, bisnis dan manajemen, serta seni/kerajinan. Jumlah SMK yang diteliti adalah 20 SMK dengan rincian SMK Bisnis berjumlah 8 , SMK Teknik berjumlah 8 , SMK Seni berjumlah 4 .

Metode yang digunakan untuk mengumpulkan data berupa kuesioner, dokumentasi dan wawancara, dengan instrumen angket, lembar pengamatan dan panduan wawancara. Untuk keperluan analisis data digunakan analisis deskriptif dalam bentuk tabulasi dan gambar.

\section{HASIL DAN PEMBAHASAN}

Dari hasil penelitian diperoleh 4 faktor utama yang menghambat perkembangan koperasi di SMK. Faktor tersebut antara lain ruang yang terbatas, manajemen, modal, dan waktu. Dari Gambar 1 terlihat bahwa faktor ruang dan waktu menjadi faktor penghambat yang menonjol untuk perkembangan kopsis di SMK wilayah Kota Yogyakarta.

Dari hasil penelitian juga ditemukan 4 faktor pendukung perkembangan kopsis SMK. Faktor pendukung itu antara lain: keberadaan pengurus, adanya pasar yang jelas, tersedianya fasilitas, dan kebutuhan lab. Dari Gambar 2 terlihat bahwa faktor pasar dan kebutuhan lab kewirausahaan menjadi faktor pendukung yang menonjol untuk perkembangan kopsis di SMK wilayah

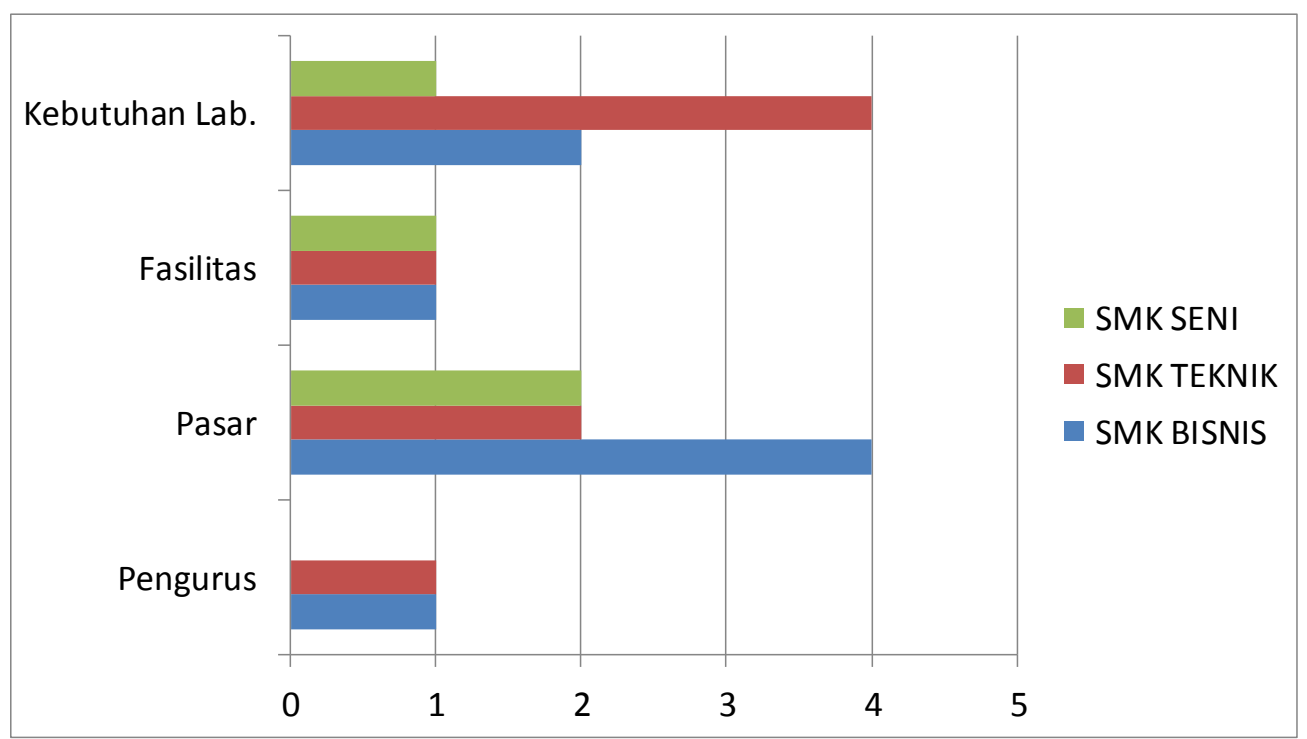

Gambar 2. Faktor pendukung

Keterangan:

1 = Tidak ada

2 = Ada, kurang lengkap, tidak teratur

3 = Ada, kurang lengkap, teratur

4 = Ada, lengkap, dan teratur 
Tabel 1. Pendidikan Karakter di Kopsis

\begin{tabular}{cll}
\hline No. & \multicolumn{1}{c}{ Nilai } & \multicolumn{1}{c}{$\begin{array}{c}\text { Bentuk Pelaksanaan Kegiatan } \\
\text { dalam Koperasi Sekolah }\end{array}$} \\
\hline 1 & Kekeluargaan & Asas kegiatan koperasi sekolah \\
2 & Kemandirian & Pengelolaan unit usaha koperasi sekolah \\
3 & Tanggung Jawab & Pemberlakuan piket di Koperasi Sekolah \\
4 & Demokrasi & Rapat Anggota/ Rapat Anggota Tahunan \\
\hline
\end{tabular}

Kota Yogyakarta. Namun untuk perkembangan koperasi siswa SMK bidang seni ada kesulitan dalam dukungan pengurus koperasi terutama dari siswa.

Pendidikan dalam koperasi bertujuan untuk memberikan pengertian dan kesadaran koperasi di kalangan anggota pada umumnya (termasuk pengurus, badan pengawas) serta untuk meningkatkan pengetahuan dan keterampilan personilpersonil yang menangani bidang usaha. Adapun indikator aplikasi nilai koperasi sekolah dapat dilihat pada Tabel 1.

Banyak manfaat diperoleh dari aktivitas pengembangan koperasi sekolah. Siswa yang aktif di kegiatan koperasi sekolah dapat memiliki kemampuan (ability) dalam bentuk pengetahuan (knowledge) sikap (attitude), dan keterampilan (skill) yang sesuai nilai-nilai dalam koperasi. Jika pendidikan perkoperasian dielaborasikan dalam bentuk yang lebih berkarakter, maka sangat membuka peluang untuk siswa dapat menjadi manusia yang memiliki kemampuan, pengetahuan, sikap, dan keterampilan berkoperasi yang baik sesuai dengan tuntutan nilai koperasi itu sendiri.

Langkah pengembangan koperasi siswa sebagai model pendidikan karakter dibagi dalam dua kegiatan, yaitu: (a) pra pengembangan, meliputi tahap define, dan tahap design; (b) pengembangan (tahap develop), ini merupakan tahap evaluasi, kegiatannya meliputi validasi, uji coba dan revisi. Berdasarkan hasil analisis kevalidan menunjukkan bahwa semua validator menyatakan bahwa model pendidikan karakter melalui pengembangan koperasi beserta perangkatnya dapat digunakan karena memenuhi kriteria valid untuk dipergunakan.

Perubahan koperasi menjadi bisnis center menjadikan kegiatan RAT dan pembagian SHU di hampir semua sekolah tidak ada. Kegiatan berkoperasi mampu menumbuhkan nilai karakter kekeluargaan, kemandirian, tanggung jawab, kejujuran, keterbukaan dan kepedulian. Pengembangan nilai/karakter dapat dilakukan dalam dua pilar, yakni kegiatan pembelajaran melalui mata pelajaran ekonomi atau kewirausahaan, serta kegiatan koperasi sekolah. Dalam kegiatan pembelajaran di kelas pengembangan nilai/karakter dilaksanakan dengan menggunakan pendekatan terintegrasi dalam semua mata pelajaran (embedded approach). Dalam lingkungan sekolah dikondisikan agar lingkungan fisik dan sosialkultural sekolah memungkinkan para peserta didik bersama dengan warga sekolah lainnya terbiasa membangun kegiatan keseharian di sekolah yang mencerminkan perwujudan nilai/karakter. Koperasi siswa dijadikan Laboratorium kewirausahaan sekolah. Dalam kegiatan koperasi sekolah banyak aktivitas 
Tabel 2. Pendidikan Karakter di Kopsis

\begin{tabular}{llccccc}
\hline \multirow{2}{*}{ No. } & \multirow{2}{*}{ Indikator Nilai Kekeluargaan } & $\begin{array}{c}\text { Jenis } \\
\text { Kopsis }\end{array}$ & STS & TS & S & SS \\
\hline 1 & Meningkatkan semangat kekeluargaan sesama & Teknik & 0,40 & 2,39 & 63,75 & 33,47 \\
& siswa & Adm/Bis & 0,39 & 1,54 & 61,00 & 37,07 \\
& & Seni & 0,00 & 0,00 & 60,44 & 39,56 \\
\hline \multirow{2}{*}{2} & Meningkatkan sikap tolong menolong sesama & Teknik & 1,20 & 0,80 & 64,14 & 33,86 \\
& siswa & Adm/Bis & 0,39 & 1,54 & 57,92 & 40,15 \\
& & Seni & 0,00 & 2,20 & 51,65 & 46,15 \\
\hline \multirow{2}{*}{3} & Memupuk rasa persaudaraan antar siswa & Teknik & 0,40 & 1,59 & 66,53 & 31,47 \\
& & Adm/Bis & 0,77 & 1,16 & 57,14 & 40,93 \\
& & Seni & 0,00 & 0,00 & 52,75 & 47,25 \\
\hline 4 & Menumbuhkan kepedulian antar siswa & Teknik & 0,40 & 1,99 & 65,74 & 31,87 \\
& & Adm/Bis & 0,39 & 1,54 & 65,64 & 32,43 \\
& & Seni & 0,00 & 1,10 & 56,04 & 42,86 \\
\hline 5 & Menumbuhkan rasa kebersamaan sesama & Teknik & 0,40 & 0,80 & 58,57 & 40,24 \\
& siswa & Adm/Bis & 0,39 & 1,93 & 56,76 & 40,93 \\
& & Seni & 0,00 & 0,00 & 56,04 & 43,96 \\
\hline
\end{tabular}

yang dapat diprogram untuk penumbuhan nilai-nilai karakter seperti jadwal piket, Rapat Anggota, unit usaha took sekolah atau kantin kejujuran, dan berbagai program koperasi.

Dari Tabel 2 terlihat bahwa menurut persepsi siswa SMK di Teknik, SMK Administrasi/Bisnis, dan SMK Seni/Kerajinan menyatakan setuju dan sangat setuju koperasi siswa mampu memupuk nilai kekeluargaan. Adapun indikator berkembangnya nilai kekeluargaan dari meningkatnya semangat kekeluargaan sesama siswa, tindakan saling tolong, peduli, dan tumbuhnya rasa kebersamaan. Hal itu

Tabel 3. Pendidikan Karakter di Kopsis

\begin{tabular}{clccccc}
\hline \multirow{2}{*}{ No. Indikator Nilai Kemandirian } & Jenis & STS & TS & S & SS \\
& & Kopsis & & & & \\
\hline 1 & Menumbuhkan kepercayaan diri siswa mampu & Teknik & 0,00 & 2,39 & 66,14 & 31,47 \\
& mengelola usaha & Adm/Bis & 0,39 & 1,54 & 60,62 & 37,45 \\
& & Seni & 0,00 & 5,49 & 73,63 & 20,88 \\
\hline 2 & Meningkatkan kepercayaan diri mampu & Teknik & 0,00 & 5,18 & 64,54 & 30,28 \\
& mengatasi permasalahan & Adm/Bis & 0,00 & 5,79 & 71,04 & 23,17 \\
& & Seni & 0,00 & 6,59 & 67,03 & 26,37 \\
\hline \multirow{2}{*}{3} & Mendidik siswa untuk tidak bergantung pada & Teknik & 0,40 & 7,17 & 60,96 & 31,47 \\
& pihak lain & Adm/Bis & 0,77 & 4,63 & 64,09 & 30,50 \\
& & Seni & 1,10 & 6,59 & 65,93 & 26,37 \\
\hline 4 & Menumbuhkan semangat untuk berani & Teknik & 0,00 & 2,79 & 62,15 & 35,06 \\
& membuka usaha & Adm/Bis & 0,00 & 0,77 & 59,07 & 40,15 \\
& & Seni & 2,20 & 4,40 & 70,33 & 23,08 \\
\hline 5 & Menumbuhkan semangat berani memanfaatkan & Teknik & 0,00 & 0,40 & 65,74 & 33,86 \\
& peluang usaha & Adm/Bis & 0,00 & 1,54 & 62,93 & 35,52 \\
& & Seni & 0,00 & 5,49 & 65,93 & 28,57 \\
\hline
\end{tabular}


berarti tidak ada beda persepsi siswa di ketiga jenis SMK terhadap penanaman nilai kekeluargaan melalui koperasi sekolah. Penanaman nilai kekeluargaan ini tercermin dari asas koperasi sekolah yang merupakan kumpulan dari orang (warga sekolah) yang menjalankan usaha bersama berdasarkan atas asas kekeluargaan.

Dari Tabel 3 terlihat bahwa menurut persepsi siswa SMK di Teknik, SMK Administrasi/Bisnis, dan SMK Seni/Kerajinan menyatakan setuju dan sangat setuju koperasi siswa mampu memupuk nilai kemandirian. Adapun indikator berkembangnya nilai kemandirian dari tumbuhnya kepercayaan diri siswa untuk mengelola usaha, mengatasi permasalahan, tidak bergantung pihak lain, berani buka usaha, dan berani memanfaatkan peluang usaha. Hal itu berarti tidak ada beda persepsi siswa di ketiga jenis SMK terhadap penanaman nilai kemandirian melalui koperasi sekolah.

Bentuk aktivitas koperasi yang menanamkan nilai kemandirian adalah pengelolaan unit usaha koperasi sekolah. Pengurus koperasi sekolah dituntut mengelola unit usaha seperti kantin maupun toko sekolah yang menyediakan sarana dan prasarana yang dibutuhkan di sekolah. Unit usaha tersebut dapat berupa layanan jasa, maupun penyediaan kebutuhan makanan dan non makanan warga yang ada di sekolah.

Dari Tabel 4 terlihat bahwa menurut persepsi siswa SMK di Teknik, SMK Administrasi/Bisnis, dan SMK Seni/Kerajinan menyatakan setuju dan sangat setuju koperasi siswa mampu memupuk nilai tanggung jawab. Adapun indikator berkembangnya nilai tanggung jawab dari piket mengelola usaha, administrasi pembukuan, menanggung risiko, laporan, dan adanya latihan melakukan pengawasan secara obyektif. Hal itu berarti tidak ada beda persepsi siswa di ketiga jenis SMK terhadap penanaman nilai tanggung jawab melalui koperasi sekolah.

Bentuk tanggung jawab dalam aktivitas kegiatan koperasi diwujudkan dalam pembagian tugas pengurus koperasi. Masingmasing bagian memiliki tugas sesuai dengan peran masing-masing seperti:

1. Ketua, bertugas mengkoordinasikan seluruh pengurus, memimpin rapat dan mewakili koperasi di dalam dan di luar

2. Sekretaris, bertugas di bidang kesekretariatan, menandatangani surat bersama ketua, serta membantu ketua koperasi dalam pelaksanaan kegiatan koperasi.

Tabel 4. Tanggung Jawab Pengurus Koperasi Sekolah

\begin{tabular}{ll}
\hline Ketua & $\begin{array}{l}\text { Bertugas mengkoordinasikan seluruh pengurus, memimpin rapat dan } \\
\text { mewakili koperasi di dalam dan di luar }\end{array}$ \\
\hline Sekretaris & $\begin{array}{l}\text { Bertugas di bidang kesekretariatan, menandatangani surat bersama } \\
\text { ketua, serta membantu ketua koperasi dalam pelaksanaan kegiatan } \\
\text { koperasi. }\end{array}$ \\
\hline Bendahara & Bertugas mengelola keuangan (administrasi keuangan) \\
\hline Stockopname & Bertugas sebagai pengontrol barang-barang yang dijual di koperasi \\
\hline Koord. Piket & Bertugas sebagai pengontrol piket pengurus koperasi \\
\hline Pengawas & Bertugas mengawasi kinerja dari pengurus koperasi \\
\hline
\end{tabular}


Jurnal Economia, Volume 12, Nomor 2, Oktober 2016

Tabel 5. Pendidikan Karakter di Kopsis

\begin{tabular}{|c|c|c|c|c|c|c|}
\hline No. & Indikator Nilai Demokrasi & $\begin{array}{l}\text { Jenis } \\
\text { Kopsis }\end{array}$ & STS & TS & $S$ & SS \\
\hline & \multirow{3}{*}{$\begin{array}{l}\text { Mendidik pengambilan keputusan secara } \\
\text { musyawarah mufakat }\end{array}$} & Teknik & 0,00 & 2,79 & 63,35 & 33,86 \\
\hline & & Adm/Bis & 0,39 & 3,47 & 59,85 & 36,29 \\
\hline & & Seni & 0,00 & 6,59 & 56,04 & 37,36 \\
\hline \multirow[t]{3}{*}{2} & \multirow{3}{*}{$\begin{array}{l}\text { Pengambilan keputusan didasarkan pada suara } \\
\text { terbanyak }\end{array}$} & Teknik & 0,00 & 9,56 & 65,34 & 25,10 \\
\hline & & Adm/Bis & 0,00 & 6,18 & 66,41 & 27,41 \\
\hline & & Seni & 1,10 & 7,69 & 63,74 & 27,47 \\
\hline \multirow[t]{3}{*}{3} & \multirow{3}{*}{$\begin{array}{l}\text { Mendidik siswa mampu menghargai pendapat } \\
\text { yang berbeda }\end{array}$} & Teknik & 0,00 & 2,79 & 58,17 & 39,04 \\
\hline & & Adm/Bis & 0,00 & 0,39 & 64,09 & 35,52 \\
\hline & & Seni & 0,00 & 3,30 & 60,44 & 36,26 \\
\hline
\end{tabular}

3. Bendahara, bertugas mengelola

Dari hasil penelitian dapat diketahui keuangan (administrasi keuangan)

4. Stockopname, bertugas sebagai bahwa pengembangan koperasi sekolah ini pengontrol barang-barang yang dijual di koperasi

5. Koordinator Piket, bertugas sebagai pengontrol piket pengurus koperasi

6. Pengawas, bertugas mengawasi kinerja dari pengurus koperasi

Dari Tabel 5 terlihat bahwa menurut persepsi siswa SMK di Teknik, SMK Administrasi/Bisnis, dan SMK Seni/Kerajinan menyatakan setuju dan sangat setuju koperasi sekolah mampu memupuk nilai demokrasi. Adapun indikator berkembangnya nilai demokrasi dari adanya latihan pengambilan keputusan dan menghargai pendapat yang berbeda. Hal itu berarti tidak ada beda persepsi siswa di ketiga jenis SMK terhadap penanaman nilai demokrasi melalui koperasi sekolah.

Bentuk aktivitas koperasi sekolah dalam penanaman nilai demokrasi yaitu adanya kegiatan Rapat Anggota Tahunan (RAT). Temuan hasil penelitian tidak semua koperasi sekolah dapat melaksanakan RAT karena berbagai alasan. masih menemui banyak kesulitan. Guru ataupun pihak sekolah belum begitu serius menangani koperasi sekolah sehingga perkembangan koperasi sekolah SMK di Yogyakarta belum memuaskan. Guru belum memiliki panduan teknis bagaimana mengembangkan koperasi sekolah untuk tujuan pengembangan karakter anak SMK. Oleh karena itu luaran dari penelitian adalah dihasilkannya Buku Panduan Pengembangan Koperasi Sekolah dan Pengembangan Karakter Anak SMK. Kendala dalam pengelolaan koperasi sekolah antara lain tugas piket yang belum 100 persen dilaksanakan, pembuatan laporan RAT pengurus sering bersamaan dengan jadwal pelajaran di kelas, keterbatasan kemampuan pengurus dalam pengelolaan keuangan koperasi sekolah termasuk laporan RAT.

\section{SIMPULAN}

Ada 4 faktor yang menghambat pengembangan koperasi sekolah, yaitu: waktu modal, manajemen dan ruang yang terbatas. Ada 4 faktor yang mendukung, yaitu: pasar, fasilitas, kebutuhan lab 
kewirausahaan, dan pengurus. Tidak ada perbedaan persepsi siswa dari SMK Teknik, SMK Administrasi/Bisnis, dan SMK Seni/Kerajinan tentang manfaat koperasi sekolah. Manfaat Koperasi Sekolah di samping memenuhi kebutuhan sekolah juga mampu menumbuhkembangkan nilai-nilai karakter kekeluargaan, kemandirian, tanggung jawab, dan demokrasi. Kendala dalam pengembangan koperasi sekolah yang ada antara lain minimnya panduan teknis pengembangan koperasi sekolah, jadwal piket yang kurang optimal, serta keterbatasan dalam pembuatan laporan RAT.

\section{DAFTAR PUSTAKA}

Anonim. (2004). Rencana Pembangunan Jangka Menengah Nasional 2005-2025. Jakarta: Sinar Grafika.

Boediono. (2012). Wirausahawan Indonesia cuma 1,56 persen. Tabengan. hal. 9 kolom 1.

Buchori Alma. (2005). Kewirausahaan. Bandung: Alfabeta.

Buchory MS \& Swadayani, T.B. (2014). Implementasi Program Pendidikan Karakter di SMP. Jurnal Pendidikan Karakter, 4(3), 235-244.

Drucker, P.F. (1985). Innovation and entrepreneurship. New York: Harper \& Row.

European Commission.

(2008)

Entrepreneurship in higher education, especially within non-business studies: Final Report of the Expert Group. Brussels: The Commission.

Ghufron, A. (2010) Integrasi Nilai-Nilai Karakter Bangsa pada Kegiatan Pembelajaran. Cakrawala Pendidikan, 29, 13-24.
Henry, C., Hill, F., \& Leitch, C. (2005). Entrepreneurship education and training: can entrepreneurship be taught? Part I. Education+ Training, 47(2), 98-111.

Jones, E., Ryan, K., \& Bohlin, K. (1999). Teachers as educators of character: Are the nation's schools of education coming up short? Washington, DC: Character Education Partnership.

Kemdiknas (2010). Desain Induk Pendidikan Karakter. Jakarta: Kementerian Pendidikan Nasional.

Kuratko, D.F. (2005). The Emergence of Entrepreneurship Education: Development, Trends, and Challenges. Entrepreneurship theory and practice. 29(5), 577-598.

Lickona, T. (1993). The return of character education. Educational Leadership, 51(3), 6-11.

Lickona, T. (1996). Eleven Principles of Effective Character Education. Journal of Moral Education, 25(1), 93-100.

Lickona, T. (1999). Character Education: Seven Crucial Issues. Action in Teacher Education, 20(4), 77-84.

Lickona, T. (2000). Character Education: The Heart of School Reform. Religion \& Education, 27(1), 58-64.

Mulyo, J. H. (2007). Revitalisasi Ekonomi Kerakyatan Melalui Pemberdayaan Gerakan Koperasi (http:// io.ppi.jepang.org/article).

Pearson, Q.M. \& Nicholson, J.T. (2000) Comprehensive Character Education in the Elementary School: Strategies for Administrators, Teachers, and Counselors. Journal of Humanistic Counseling, Education and Development, 38, 243-251.

Peraturan Presiden RI Nomor 7 Tahun 2005 Tentang Rencana Pembangunan Jangka Menengah Nasional (RPJMN) 2004-2025. 
Priambodo. (2006). Koperasi Sekolah: Titik Masuk Menguasai "Lingkaran Setan" Pengangguran dan Kewirausahaan. Jurnal Infokop. No.28 Tahun XXII. 2006 Jakarta: Dekopin.

Ryan, K. (1993). Why a center for the advancement of ethics and character. Journal of Education, 175(2), 1-12.

Sarasvathy, S.D. \& Venkataraman, S. (2011). Entrepreneurship as Method: Open Questions for an Entrepreneurial Future. Entrepreneurship theory and practice. 35(1), 113-135.

Sukidjo. (2008). Membangun Citra Koperasi. Jurnal Ekonomi \& Pendidikan. 5(2), 193203.

Suranto AW. (2014). Integrasi Pendidikan Karakter dalam Pembelajaran Mata Kuliah Komunikasi Interpersonal. Jurnal Pendidikan Karakter, 4(3), 225-234.

Tanjung, R., \& Ramadhani, H. (2013). Pengaruh Model Pembelajaran Kooperatif Tipe STAD dengan Integrasi
Karakter Terhadap Pembentukan Karakter dan Hasil Belajar Siswa pada Materi Pokok Listrik Dinamis di SMA Negeri 1 Stabat. Prosiding Semirata FMIPA Universitas Lampung, 329-344.

Tonelli, M. \& Dalglish, C.L. (2012). Entrepreneurial Becoming - A SelfInduced Transformation. ACE Research Vignette, 20.

Undang-Undang Dasar 2004 (UUD 1945 yang diamandemen yang ke empat).

Undang-Undang No. 20 Tahun 2003 Tentang Sistem Pendidikan Nasional.

Undang-Undang No. 25 Tahun 1992 Tentang Perkoperasian.

Wiliams, M.M. (2000). Models of Character Education: Perspectives and Developmental Issues. The Journal oh Humanistic Counseling, 39(1), 32-40.

Zuchdi, D. (2009). Pendidikan karakter grand design dan nilai-nilai target. Yogyakarta: UNY Press. 